NBER WORKING PAPER SERIES

\title{
WELFARE MAGNET HYPOTHESIS, FISCAL BURDEN AND IMMIGRATION SKILL SELECTIVITY
}

\author{
Assaf Razin \\ Jackline Wahba \\ Working Paper 17515 \\ http://www.nber.org/papers/w17515 \\ NATIONAL BUREAU OF ECONOMIC RESEARCH \\ 1050 Massachusetts Avenue \\ Cambridge, MA 02138 \\ October 2011
}

Financial support from NORFACE research programme on Migration in Europe - Social, Economic, Cultural and Policy Dynamics is acknowledged. The views expressed herein are those of the authors and do not necessarily reflect the views of the National Bureau of Economic Research.

NBER working papers are circulated for discussion and comment purposes. They have not been peerreviewed or been subject to the review by the NBER Board of Directors that accompanies official NBER publications.

(C) 2011 by Assaf Razin and Jackline Wahba. All rights reserved. Short sections of text, not to exceed two paragraphs, may be quoted without explicit permission provided that full credit, including @ notice, is given to the source. 
Welfare Magnet Hypothesis, Fiscal Burden and Immigration Skill Selectivity

Assaf Razin and Jackline Wahba

NBER Working Paper No. 17515

October 2011

JEL No. F22,H3,J48

\begin{abstract}
This paper revisits the magnet hypothesis and investigates the impact of the welfare generosity on the difference between skilled and unskilled migration rates. The main purpose of the paper is to assess the role of mobility restriction on shaping the effect of the welfare state genrosity. In a free migration regime, the impact is expected to be negative on the skill composition of migrants while in a restricted mobility regime, the impact will be the opposite, as voters will prefer selective migration policies, favoring skilled migrants who tend to be net contributors to the fiscal system. We utilize the free labor movement within EUR (the EU, Norway and Switzerland) and the restricted movement from outside of the EUR to compare the free migration.
\end{abstract}

\author{
Assaf Razin \\ Department of Economics \\ Cornell University \\ Uris 422 \\ Ithaca, NY 14853 \\ and Cornell University \\ and also NBER \\ ar256@cornell.edu \\ Jackline Wahba \\ Economics Division \\ School of Social Sciences \\ University of Southampton \\ Southampton, SO17 1BJ \\ United Kingdom \\ J.Wahba@soton.ac.uk
}


regime to the restricted migration regime. We find strong support for the "magnet hypothesis" under the free-migration regime, and the "fiscal burden hypothesis" under the restricted-migration regime even after controlling for differences in educational quality and returns to skills in source and host countries.

\section{Introduction}

This paper aims at revisiting the social magnet hypothesis in international migration. It investigates the impact of the generosity of the welfare state in attracting migrants from abroad. The paper looks specifically at the skill composition of migration patterns, highlighting the difference between skilled and unskilled migration rates. The novelty of the paper is in looking at the role of mobility restrictions in shaping the effect of the welfare state on migration. In a free migration regime, the impact on the skill composition is expected to be negative while in a restricted regime, the impact might be the opposite one, as voters will prefer selective migration policies favoring skilled migrants who tend to be net contributors to the fiscal system.

Public debate on immigration has increasingly focused on its effects on the welfare state, amid concerns that immigrants are a fiscal burden. For example, the average aggregate social spending as a percent of GDP for EU14, Norway and Switzerland, between 1980 and 1995, was around 21 percent, compared to around 18 percent in the US, 17 percent in Canada, and 13 percent in Australia. An interesting differential characteristic of immigration between the EU14/Norway/Switzerland (EUR) and the US/Canada/Australia 
is the higher relative skill composition of immigrants in the latter countries (see Table 1). ${ }^{1}$ On first glance, this suggests that countries that have generous welfare systems also have relatively more unskilled immigrants, i.e. welfare state generosity acts as a magnet for unskilled migrants. However, the skill composition of immigrants depends on many factors, and in particular on the policy regime; namely whether migration is free or restricted. In other words, the generosity of the welfare state may affect the skill composition of immigrants differently, depending on which immigration policy is adopted. The generosity of the welfare state determines the self-selection of potential migrants (supply-side mechanism) and the immigration policy in the destination country (demand-side mechanism). This paper takes advantage of heterogeneous bilateral immigration policies to identify and quantify these two mechanisms. The paper investigates how the skill composition of migration patterns differ between free and restricted migration regimes. It tests how the generosity of the welfare state affects the skill composition of the immigrants across these policy regimes.

There has been large body of research on welfare migration, though with mixed results. ${ }^{2}$ For example, Borjas (1999), Enchautegui (1997) and McKinnish (2007) for the US and De Giorgi and Pellizzari (2006) for Europe ${ }^{3}$ show

\footnotetext{
${ }^{1}$ Docquier, Rapoport and Salomone (2011) classify host countries into five main groups based on their immigration policies. They argue that Europe has low restrictiveness in their immigration policies, while Western offshoots (USA, Canada, Austraila) are more skill-selective.

${ }^{2}$ See Brueckner (2000) for a review of this literature.

${ }^{3}$ See also Khoudour-Castéras (2008) who studies emigration from 19th century Europe. He finds that the social insurance legislation, adopted by Bismarck in the 1880s, reduced the incentives of risk averse Germans to emigrate. He estimates that in the absence of
} 
how the welfare-state generosity works effectively as a magnet to migrants. On the other hand, Levine and Zimmerman (1999), show that welfare benefits have little effect on the probability of female-headed households (the recipients of the benefits) to relocate in the US and Gelbach (2004) finds strong evidence of welfare migration in 1980, but less in 1990 for the US. However, none of those studies control for the migration regime. ${ }^{4}$ Studies of migration between states within the US can help only in providing evidence of a freemigration regime. On the other hand, studies that employ samples confined to the policy-controlled migration regime, but at the same time employ a model of the migrants' choice whether to migrate and to which country, are evidently problematic. In this case, the estimates convey little information about the migrants' choices (and hence on the welfare state as a magnet to unskilled migrants), but rather on the migration policy choices of the host country. Finally, studies that refer to both migration regimes without controlling for them are problematic because they do not disentangle migration policies in the host countries, and the individual migrant's migration choices in the source countries.

We use 14 core EU countries (old member states) plus Norway and Switzerland (EUR thereafter) to study empirically the policy-regime differential effect of the generosity of the welfare state on the skill composition of migration rates. Freedom of movement and the ability to reside and work anywhere within the EU are two of the fundamental rights which EU member

social insurance, the German emigration rate from 1886 to 1913 would have been more than double its actual level.

${ }^{4}$ An exception is the unpublished paper by Cohen and Razin (2009) which we follow and extend. 
states must recognize and this extends through bilateral treaties also to Norway and Switzerland. In contrast, labor mobility into EUR member states from non-EUR states is still restricted. The paper utilizes this difference in policy regimes between EUR and non-EUR states, to test the key differences between free- and policy-restricted migration.

The paper has four main features. First, since welfare benefits might be one factor affecting the skill composition of migration rates, we control for other potential factors that are likely to affect the selectivity of migration. As Roy (1951) and Borjas (1987) argue the characteristics of those who emigrate from a particular country will depend on that country's wage distribution. In poor countries, where the returns to skills are relatively high, there will be a "negative selection" of immigrants; whilst in rich countries, where returns to skills are relatively low, there will be "positive selection" of immigrants. Thus we control for both returns to skills in the source country measured by income inequality, as well as for the wage-premium skill differential in the host country. Second, the paper considers, and distinguishes between, immigration from developing source countries as well as developed ones, since the magnet effect of the generosity of the welfare state on the immigrant skill composition, and the fiscal burden effect of these immigrants may be different for (poor) developing countries compared to those from richer developed ones. Third, because a proper measure of immigrant skill is key to our analysis, we correct for educational quality an issue ignored in the empirical migration literature. In this way we attempt to obtain a relatively homogeneous classification of skill levels using the Hanushek-Woesmann (2009) measure of cognitive skills. Finally, we also control for the potential endo- 
geneity problem : the skill composition of migration itself may influence the voters' attitude towards the generosity of the welfare state.

The rest of the paper is structured as follows. Section two provides the theoretical framework underpinning our empirical analysis. Section three presents the data sources and discusses the schooling quality measure. Section four presents the econometric model and compares the findings for LDC source countries relative to DC source countries. Section five concludes.

\section{Theory}

We present a minimalist model which features two migration regimes: free migration and policy controlled migration regimes. ${ }^{5}$ In a nutshell, the policycontrolled migration regime leads to a positive impact of the welfare benefits on the skill composition of migration rates since voters will internalize the fact that skilled migrants will be net contributors to the system- the fiscal burden effect-, whereas unskilled migrants will be net beneficiaries- the social magnet effect. Under the free migration regime the unskilled migrants will gravitate to a generous welfare state, while skilled migrants will shy away.

\section{$2.1 \quad$ Model}

There is a continuum of workers, where the number of native born is normalized to 1. Assume a Cobb-Douglas production function, with two labor

\footnotetext{
${ }^{5}$ See Razin, Sadka and Suwankiri (2011) for a more elaborate model.
} 
inputs, skilled and unskilled:

$$
Y=A L_{e}^{\alpha} L_{u}^{1-\alpha}, 0<\alpha<1
$$

where, $Y$ is the GDP, $A$ denotes a Hicks-neutral productivity parameter, and $L_{i}$ denotes the input of labor of skill level $i$, where $i=e, u$ for skilled and unskilled, respectively.

The competitive wages of skilled and unskilled labor are equal to marginal productivity, respectively

$$
\begin{gathered}
w_{e}=\alpha Y / L_{e} \\
w_{u}=(1-\alpha) Y / L_{u} .
\end{gathered}
$$

Aggregate labor supply, for skilled and unskilled workers, respectively, is given by:

$$
\begin{gathered}
L_{e}=(e+\sigma \mu) l_{e} \\
L_{u}=(1-e+(1-\sigma) \mu) l_{u} .
\end{gathered}
$$

where $e$ denotes the share of native born skilled in the total native born labor supply; $\sigma$ denotes the share of skilled migrants in the total number of migrants; $\mu$ denotes the total number of migrants; and $l_{i}$ is the labor supply of an individual with skill level $i \in\{e, u\}$.

Total population (native born and migrants) is:

$$
N=1+\mu .
$$

We specify a simple welfare-state system which levies a proportional labor income tax at the rate $\tau$, with the revenues redistributed equally to all 
residents (native born and migrants alike) as social benefit per capita, $b$. The social benefit captures not only a cash transfer but also outlays on public services, such as education, health, and other provisions, that benefit all workers, regardless of their contribution to the tax revenues.

The government budget constraint is therefore

$$
N b=\tau Y .
$$

Assume that the utility function for skill-type $i \in\{e, u\}$ is :

$$
u_{i}=c_{i}-\frac{\varepsilon}{1+\varepsilon} l_{i}^{\frac{1+\varepsilon}{\varepsilon}}
$$

where $c_{i}$ denotes consumption of an individual with skill level $i, l_{i}$ denotes the individual labor supply and $\varepsilon>0$.

The budget constraint of an individual with skill level $i$ is

$$
c_{i}=b+(1-\tau) l_{i} w_{i} .
$$

Individual utility-maximization yields the following labor supply equation

$$
l_{i}=\left((1-\tau) w_{i}\right)^{\varepsilon} .
$$

It is then straightforward to calculate the general equilibrium wages for skilled and unskilled workers, which are given respectively by

$$
\begin{gathered}
w_{e}=A\left(\alpha \delta^{\varepsilon} \theta^{1-\alpha}\right)^{\frac{1}{1+\varepsilon}} \\
w_{u}=A\left((1-\alpha) \delta^{\varepsilon} \theta^{-\alpha}\right)^{\frac{1}{1+\varepsilon}} \\
\text { where } \delta \equiv \alpha^{\alpha}(1-\alpha)^{1-\alpha} \\
\text { and } \theta \equiv \frac{1-e+(1-\sigma) \mu}{e+\sigma \mu} .
\end{gathered}
$$


In order to ensure that the skilled wage always exceeds the unskilled wage, $w_{e}>w_{u}$, we assume that

$$
\frac{\alpha(1-e+(1-\sigma) \mu)}{(1-\alpha)(e+\sigma \mu)}>1
$$

\subsection{Policy-controlled Migration}

Assume that the host country faces abundant supply of migrants of each one of the two skill types, so that host-country migration policy is the sole determinant of migration flows. The policy is determined by the median voter in the host country. Let us assume that the policy decisions on the tax rate, $\tau$, and the total volume of migration, $\mu$, are exogenous. We do this in order to focus the analysis on a single endogenous policy variable, which is the skill composition of migrants, $\sigma$. Note that once $\sigma, \mu, \tau$ are determined, then the social benefit per capita, $b$, is given by the government budget constraint; we thus denote the social benefit per capita $b$ as $b(\sigma ; \tau)$; where the exogenous variable $\mu$ is suppressed.

The indirect utility of an individual with skill level $i$ is given by:

$$
V_{i}(\sigma ; \tau)=b(\sigma ; \tau)+\frac{1}{1+\varepsilon}\left[(1-\tau) w_{i}(\sigma ; \tau)\right]^{1+\varepsilon}
$$

Differentiating the equation with respect to $\sigma$, and employing the envelope theorem, yields

$$
\frac{d V_{i}(\sigma ; \tau)}{d \sigma}=\frac{d b(\sigma ; \tau)}{d \sigma}+(1-\tau) l_{i}\left(w_{i}(\sigma ; \tau)\right) \frac{d w_{i}(\sigma ; \tau)}{d \sigma}
$$

Thus, a policy induced change in the share of skilled migrants in the total number of migrants, $\sigma$, affects the utility level through two channels. First, an increase in $\sigma$ raises average labor productivity and thereby tax revenues. 
This, in turn, raises the social benefit per capita, $b$. Second, an increase in $\sigma$, which raises the supply of skilled labor relative to the supply of unskilled labor, depresses the skill-premium in the labor market. If the decisive voter is unskilled, both of the above effects increase her utility. Thus, an unskilled voter would like to set the skill-composition of migrants at the maximal limit, $\sigma=1$. This means that the share of skilled migrants preferred by the decisive skilled voter is typically lower than that preferred by the decisive unskilled voter. The decisive skilled voter would like to set $\sigma$ below 1 (which is equivalent to assuming that the first-order condition is met before $\sigma$ reaches $1)$.

Defining $\sigma^{i}$ as the share of skilled immigrants most preferred by an individual with skill level $i=e, u$ in the host country, we get

$$
\sigma^{e}<\sigma^{u}=1
$$

Recall that the purpose is to find the effect of the change in the generosity of the welfare state on the migration policy concerning $\sigma$. The generosity of the welfare state, captured by the magnitude of the social benefit per capita, $b$, which depends positively on the tax rate, $\tau$ (we assume that economy is on the "correct side" of the Laffer curve). We thus look for the effect of an increase in $\tau$ on the change in the skill composition of the migrants, $\sigma$. It can be shown that:

$$
\frac{d \sigma^{u}}{d \tau}=0 ; \frac{d \sigma^{e}}{d \tau}>0 .
$$

This means that, if the decisive voter is an unskilled worker, an increase in the tax rate, $\tau$, would leave the skill migration policy unchanged, because it is always set at the maximum possible limit. If, however, the decisive 
voter is a skilled worker, an increase in the tax rate, $\tau$, will change the policy concerning the skill-composition of migrants in the direction towards a larger share of skilled migrants. The reason is that when the tax rate is higher, the redistribution burden upon a skilled decisive voter increases. Allowing an additional skilled migrants can ease this rise in the fiscal burden. Note also that the result applies to the skill mix of migration rates.

\subsection{Free Migration}

We now assume that no restrictions are placed on migration by the policy makers in the host country. The level of migration depends entirely on the choice made by would be potential migrants. In choosing whether to migrate or not, a potential migrant of skill $i$ compares his prospective utility, $V_{i}$, in the migration destination, to the reservation utility, denoted by $\bar{u}^{i}$ in the source country. For each skill level $i$, we assume that there is a continuum of would-be migrants, different with respect to the reservation utility level in the source country. This heterogeneity of reservation utilities in the source country could stem from different traits of the potential migrants (e.g., family size, age, moving costs, forms of portable pensions, housing, cultural ties,

etc.). Thus the host country faces an upward sloping supply curve, $S\left(V_{i}\right)$, of potential migrants from the source country, for each skill level $i$.

Let $m_{e}$ be the number of skilled migrants, and $m_{u}$ is the number of unskilled migrants. The proportion of skilled migrants, $\sigma$, is defined then by:

$$
\sigma=\frac{\frac{m_{e}}{m_{u}}}{1+\frac{m_{e}}{m_{u}}}
$$


The indirect utility function in the host country is given by:

$$
V_{i}(\tau)=b(\tau)+\frac{1}{1+\varepsilon}\left((1-\tau) w_{i}\right)^{1+\varepsilon}
$$

The following equation determines, for each $\tau$, the cut-off levels of the reservation utilities $\left(\bar{u}^{e}(\tau)\right.$ and $\bar{u}^{u}(\tau)$, for a would-be migrant of skill $i=e, u$, as follows:

$$
V_{i}(\tau)=\bar{u}^{i}(\tau)
$$

That is the marginal would be migrant is indifferent between staying in the source country or leaving to the destination country. We can use this equation to find the number of migrants for each skill level. By definition, the number of migrants of each skill level, $i=e, u$, is determined by the supply of migrants for $i=e, u$, that is

$$
m_{i}(\tau) \equiv S^{i}\left(\bar{u}^{i}(\tau)\right)
$$

We now attempt to find the effect of an exogenous change in the generosity of the welfare state proxied by $\tau$ on the skill mixture of the migrants. It could be shown that:

$$
\frac{d \sigma}{d \tau}<0
$$

The rationale for this result is as follows. An increase in $\tau$ raises the social benefit per capita, $b$, but lowers the net wage, $(1-\tau) w_{i}$. For skill migrants, the fall in net wage outweighs the increase in the social benefit per capita. Thus, an increase in $\tau$ reduces the well-being of skilled workers. Consequently, an increase in $\tau$ reduces the cut-off reservation utility of skilled migrants, $\bar{u}^{e}(\tau)$. As a result, those skilled migrants with reservation utilities between the pre-increase level and the new cutoff level will choose not to migrate. The opposite holds true for unskilled migrants. Thus an increase 
in the generosity of the welfare state under free migration deters skilled migrants and attracts unskilled ones, thereby tilting the skill composition of migration towards unskilled migrants. The result does not apply only to the skill mix among migrants; note that the skill mix in migration rates is also tilted towards unskilled migrants. This is the magnet effect of the welfare state.

\section{Empirical Analysis}

Our aim is to test how the generosity of the welfare state affects the skill difference in migration rates into EUR countries across policy regimes for both developing and developed source countries after controlling for returns to skills in source and host countries. It is common to focus on developed countries (OECD countries) where skill levels (usually proxied by education attainment) are comparable given the potential heterogeneity in education quality across developed and developing countries.

\subsection{Data}

We decompose our sample into three groups as follows. ${ }^{6}$ Group A (EUR to EUR) contains only the source-host pairs of countries which allow free mobility of labor between them, according to the single-market treaty. Any kind of discrimination between native-born and immigrants, regarding labor market accessibility and welfare-state benefits eligibility is illegal. These are

\footnotetext{
${ }^{6}$ Our sample of source countries is dictated by data availability on educational quality.
} 
16 European countries (EUR): Austria, Belgium, Denmark, Finland, France, Germany, Greece, Ireland, Italy, Netherlands, Portugal, Spain, Sweden, UK, Norway and Switzerland.

Group B (EUR and DC to EUR) includes only the developed sourceEUR host pairs of countries within which the source country residents cannot freely move, work and receive social benefits in any of the host countries. The source countries, however, are 10 developed countries: US, Canada, Japan, Australia, New Zealand, Israel, Taiwan, Hong Kong, Korea and Singapore.

Group C (EUR and LDC to EUR) includes the developing source-EUR host pairs of countries in which the source country residents cannot freely move, work and receive social benefits in any of the host countries. Twenty three developing countries are included: Argentina, Brazil, Chile China, Colombia, Ecuador, Egypt, Jordan, India, Indonesia, Iran, Malaysia, Mexico, Morocco, Lebanon, Nigeria, Peru, Philippines, Tunisia, South Africa, Thailand, Turkey and Venezuela.

We only consider immigration to EUR host countries. We distinguish between LDC and DC source countries and run separate regressions in order to compare the effect of the welfare state in both cases. The determinants of emigration and the effects of the generosity of the welfare state are likely to be different for poor developing countries relative to richer, developed ones:- e.g., the gap between the host and source countries in terms of wages, amenities, social spending and welfare are larger for developing countries.

The analysis uses bilateral migration data from Docquier and Marfouk (2006). The data contain bilateral immigrant stocks, based on census and register data, for the years 1990 and 2000. Immigrants of a working age (25+) 
are defined as foreign-born. The immigrants are classified into three education levels: low-skilled (0-8 schooling years), medium-skilled (9-12 schooling years) and high-skilled (13+ schooling years). The data also contain the stock of the domestic-origin labor force for all the countries.

Data for social spending is based on the OECD's Analytical Database (average for 1974-1990). Social expenditure encompass all kinds of social public expenditures, in cash or in kind, including, for instance, old-age transfers, incapacity related benefits, health care, unemployment benefits and other social expenditure. Social spending is in PPP 1990 US dollars and is divided by the population of the host country to provide per capita benefits. Our use of social spending per capita is motivated by the theory in section 2 , where social benefits per capita are the indicator of the generosity of the welfare state. We also check the robustness of this measure using social spending as a share in GDP, average for 1980-1990 based on OECD SOCX.

Examining the non-parametric evidence based on our sample, Table 2 shows, for example, that Sweden a highly generous welfare state attracts higher rate of unskilled than skilled (about 30\% higher) from other EUR whereas Spain a less generous welfare state attracts higher rate of skilled than unskilled migrants (48\% higher) from other EUR. A the same time, in both countries immigration rates from restricted regimes (both DC and LDC) are more skilled than those from free migration regimes (EUR). It is also worth noting that there is also high correlation between the two indicators of the generosity of the welfare state, social expenditure as percent of GDP and social expenditure per capita. 


\subsection{Quality of Education and Enforcement of Immi- gration Policies}

Since our interest is in the effect of the generosity of the welfare state on the skill composition of migration rates, controlling for the heterogeneity in the skill (education) measurement is essential. Indeed, Coulombe and Tremblay (2007) show that measuring human capital using an output measure matters considerably when assessing the contribution of immigrants in Canada, coming from a wide range of countries. Ignoring differences in the educational quality of source countries is likely to introduce a bias in estimates of the generosity. On one hand, if immigration policies favor higher educational attainment immigrants and one does not control for educational quality, this would tend to produce an overestimate of the effect of generosity on the skill composition for LDC source countries. On the other hand, if high educated immigrants are of poor quality, then their productivity would not be that different from their low-skilled counterparts: they would behave similar to the low-skilled migrants, as being net beneficiaries, rather than net contributors to the welfare state. This results in an underestimate of the generosity coefficient. To address this potential problem, we adjust all the migration stocks and rates for quality of education, using Hanushek and Woessmann (2009) new measures of international differences of cognitive skills.

Hanushek and Woessmann (2009) use international assessments of student achievement such as the First International Mathematics Study (FIMS), the Trends in International Mathematics and Science Study (TIMSS) and the Programme for International Student Assessment (PISA). A total of 12 international student achievement tests (ISATs) were collected. Although 
varying across the individual assessments, to obtain a common measure of cognitive skills, they rely upon information about the overall distribution of scores on each ISAT to compare national responses. In order to compare performance on the ISATs across tests and over time, they project the performance of different countries on different tests onto a common metric. For that, they develop a common metric both for the level and for the variation of test performance. To make the level of ISATs comparable, they use the only available information on educational performance that is consistently available for comparisons over time: namely, in the form of the National Assessment of Educational Progress (NAEP) from the United States, which has tested the math, science and reading performance of nationally representative samples of 9-, 13-, and 17-year-old US students in an intertemporally comparable way since 1969. The United States is also the only country that has participated in every ISAT.

Their main measure of cognitive skills is a simple average of all standardized math and science test scores of the ISATs in which a country participated. They use a group of countries to serve as a standardization benchmark for performance variation over time, and choose 13 OECD countries that already had substantial enrollment in secondary education in 1964 and have had relatively stable education systems, which they term the "OECD Standardization Group" (OSG) of countries. Then for each assessment, they calibrate the variance in country mean scores for the subset of the OSG participating to the variance observed on the PISA tests in 2000 (when all OSG countries participated). By combining the adjustments in levels (based on the US NAEP scores) and the adjustment in variances (based on the OSG), 
they directly calculate standardized scores for all countries on all assessments. Each age group and subject is normalized to the PISA standard of mean 500 and individual standard deviation of 100 across OECD countries (see Appendix B in Hanushek and Woessmann (2009) for full details).

Hanushek and Woessmann (2009) use their schooling quality measure to provide evidence on the robust association between cognitive skills and economic growth. They also find that home-country cognitive-skill levels strongly affect the earnings of immigrants in the US labor market in a difference-in-differences model that compares home-educated to US-educated immigrants from the same country of origin. Thus suggesting that controlling for the quality of schooling is important.

We use their imputed average test scores in math and science for primary through end of secondary school, all years (scaled to PISA scale divided by 100) for all source countries in our sample as our measure of Education Quality (EQ). ${ }^{7}$ We adjust for varying quality of education across countries by using relative quality of education in the source country relative to that in the host country $R E Q=E Q_{s} / E Q_{h}$ and interact that with the migration stocks. It is important to note two caveats due to the constraints of this quality measure. First, this quality measure does not vary over time since it is an average for various years thus we use the same measure for migration stocks in the 1990s and 2000s. Second, we use the same quality measure for the three educational levels. However, we check the robustness of our results using different methods to adjust for quality of education across countries.

\footnotetext{
${ }^{7}$ Coulombe and Tremblay (2007) provide an alternative way to correcting for differences in education quality. They use skill-schooling gap.
} 
Table A1 shows the test scores for math and science scores based on Hanushek and Woessmann (2009). One interesting issue is that education quality varies not only between developed and developing countries but also between developed countries and EUR: the average for EUR is 4.939, whilst for DCs it is 5.132 and for LDCs it is only 3.99. This suggests that there might be a need to control for quality of education not only when considering developing countries but also developed ones. Table A2 provides a numerical example of how we adjust for educational quality. For example, the unadjusted Egypt-UK migration rate is 0.244 , while the adjusted one using the Relative Education Quality index is 0.198 .

\section{The Econometric Model}

\subsection{Regression Specifications}

To estimate the differential impact of the welfare state generosity on the skill difference in migration rates, one would ideally like to use flows rather than stocks. However, our data is in stocks. We therefore specify the flows in two ways: indirect way and direct one. The indirect way is to have the stock variable as a dependent variable and a lagged stock variable as an explanatory variable; effectively measuring the effect of all other explanatory variables on the difference between the dependent variable and its lagged counterpart. Alternatively, we use as the dependent variable the difference in the stock variables in the two distinct time points. ${ }^{8}$

\footnotetext{
${ }^{8}$ Beine, Docquier and Ozden (2011) take the difference in stocks as a measure for flows.
} 
We specify migration selectivity, following Grogger and Hanson (2011), by differences in migration rates. $m_{s, h, t}^{i}$ denotes the stock of migrants of skill level $i$ (comprised of $e$ skilled and $u$ unskilled), who originated from source country $s$ and reside in host country $h$, as a ratio of the stock of all native workers $P_{s, t}^{i}$ of skill level $i$ in the source country $s$ in $t$, the year 2000. Since our key hypothesis is that the effect of welfare benefits on the skill selectivity of immigrants vary according to the immigration regime, we use the skill difference in the migration rates as follows:

$$
m_{s, h, t}^{e} / P_{s, t}^{e}-m_{s, h, t}^{e} / P_{s, t}^{u}=D M_{s, h, t}
$$

Thus, the skill difference selection equation is where the dependent variable is $D M_{s, h}$ measuring the skill difference in selectivity of migrants, $\mathrm{t}=$ the year 2000 and $t-1=$ the year 1990 :

$D M_{s, h, t}=\beta_{0}+\beta_{1} D M_{s, h, t-1}+\beta_{2} B_{h}+\beta_{3}\left(R_{s, h} B_{h}\right)+\beta_{4} R_{s, h}+\beta_{5} X+\beta_{6} R_{s, h} X+\mu_{s, h}$

$D M_{s, h, t}-\beta_{1} D M_{s, h, t-1}=\beta_{0}+\beta_{2} B_{h}+\beta_{3}\left(R_{s, h} B_{h}\right)+\beta_{4} R_{s, h}+\beta_{5} X+\beta_{6} R_{s, h} X+\varepsilon_{s, h}$

The first specification 1a (eqn 20) with lagged dependent variable refers to the indirect way of measuring the effect of generosity on the flow variable; 
whereas the second specification $1 b$ (eqn 21) refers to the direct way of doing so where the dependent variable is the difference between $2000(t)$ and 1990 $(t-1)$.

$B_{h}$ denotes the log average benefits per capita in host country $h$ over the period 1974-1990 and $R_{s, h}$ is a policy regime dummy variable, which equals 0 if the source-host pair exercises free migration, and 1 otherwise. In our sample, only migration between EUR countries is free $\left(R_{s, h}=0\right)$. Immigration to EUR from non-EUR DCs or LDCs is restricted $\left(R_{s, h}=1\right)$. We collect all the other controls in $X$ (bilateral, host, or source) and discuss in details below. A positive coefficient indicates a positive effect on the skill composition measure of the migrants, and vice versa.

Note that the effect of welfare state generosity on the skill difference selectivity of the migrants under free migration is captured in the above equation by the coefficient $\beta_{2}$. Therefore, the null hypothesis describing this effect is:

$$
\beta_{2}<0
$$

In addition, the effect of welfare state generosity on the skill difference selectivity of migration rates in the case of restricted migration is captured by the coefficient $\beta_{2}+\beta_{3}$. Therefore the null hypothesis describing this effect is:

$$
\beta_{3}>0
$$




\subsection{Controls}

We control for other factors that are likely to be skill dependent as follows. First, we attempt to control for other immigration policy measures in the host country that might have an effect on the skill composition of immigrants. We use refugees as a share in total immigrants in 1990 in the host country based on the United Nations Population Division Statistics. ${ }^{9}$ To capture the effect of family re-unification schemes adopted in host countries we use the stock of past migrants from the source country in the host country in 1990. Both variables are expected to have a negative impact on the migrant skill mix, since both policies attract low-skilled migrants.

One important determinant of migration is the wage differential or the skill differential between source and host countries. We use real GDP per capita (PPP) in 1990, constant US dollars, for both host and source countries in the absence of data on wages in the source countries. We also use average unemployment rates (average for 1990-1995) in both source and host countries. $^{10}$

To capture better the Roy-Borjas selectivity factors which are likely to affect immigration selectivity, we use a battery of controls: (i) inequality measure (the Gini coefficient) in the source country in $1990 ;{ }^{11}$ (ii) as a proxy

\footnotetext{
${ }^{9}$ Unfortunately, we were not able to obtain data on the number or share of refugees for source-host pairs. We have also experimented with using the number of refugees and asylum seekers in the host in 1997, and all our results were robust.

${ }^{10}$ Both GDP per capita and unemployment rates are from the World Bank World Development Indicators.

${ }^{11}$ Data on the Gini coefficient are from the UNU-WIDER World Income Inequality Database (WIID) 2008.
} 
for the returns to skill in the host country, the log value of the skilledunskilled native labor stock ratio in $1990^{12}$; (iii) instead of (ii), for the host country, the ratio of skilled-unskilled wage differential measured by the ratio of labor compensation per employee in US dollars PPP in $1995^{13}$; and (iv) the difference in unemployment rates between the skilled and unskilled in the host country in $1998 .^{14}$

Additional bilateral controls, such as the distance between source-host countries, which might deter unskilled immigrants more than skilled ones, strong relation dummy based on past colonization, and same-language in source-host countries, which might make immigration particularly attractive for unskilled workers are included. We also control for quantity of education using average years of schooling $(+25$ years $)$ in the source country, extracted from the World Bank World Development Indicators, in addition to adjusting for educational quality as mentioned above. As a robustness check we also use fixed effects for source country in order to capture all potential push factors. We also use clustering for each pair of source-host countries.

\footnotetext{
${ }^{12}$ The last two control variables do not add up to one because we omitted workers with fewer than eight years of schooling.

${ }^{13}$ Skilled is financial and business services and unskilled is construction. Source OECD Stat.

${ }^{14}$ Unemployment rates of the population aged $25-64$ by level of education; skilled is defined as upper secondary and post-secondary non-tertiary education levels 3-4 (ISCED, 1997) and unskilled is defined as pre-primary, primary and lower-secondary education levels 0-2 (ISCED, 1997). Source: Eurostat.
} 


\subsection{Endogeneity of The Welfare State Generosity}

A potential endogeneity problem may arise - in particular between the level of benefits in the host country, $B_{h}$, and the skill difference in the migration rates, because skilled immigrants can influence the political economic equilibrium level of benefits. For example, more immigration may lead to lower level of social spending per capita if migrants are more likely to become unemployed, or if migrants come with large dependent families. We use the instrumented lagged level of benefits per capita in the host country, $B_{h}$ (the average for 1974-1990). To instrument $B_{h}$ we use the legal origin in the host country (English, Scandinavian, French or German) as an instrument. We also instrument the interaction $R_{s, h}$. $B_{h}$ using the interaction between the legal origin and $R_{s, h}$. The legal system indicates cultural and social features of the host countries and reflect also basic constitutional notion regarding the attitude towards property rights on the one hand, and social rights on the other hand. Indeed we find a strong correlation between the legal origin and the welfare benefits (cor $=60 \%$ ). One concern might be that legal origin might be correlated with, for example, an omitted variable such as the economic development which is known to affect migration, and that could potentially undermine the validity of the exclusion restriction. The empirical literature, however, is mixed with respect to whether legal origin has a significant impact on economic development. For example, Acemoglu and Johnson (2005) do not find evidence that the legal system significantly affect economic growth. However to ensure that this is not a possible channel for us, we include GDP growth rate in the host country as a control variable. In that way the only open channel for legal origin to affect migration is through 
the instrumented $B_{h}$. But in fact we don't find GDP growth rate to be significant.

\section{Main Findings}

\section{$5.1 \quad$ Specification 1a}

We first examine the estimates for Specification 1a. Table 3 presents the OLS estimation results for both DCs and LDCs for our variables of interest. Our first hypothesis relates to the effect of welfare state benefits on the skill difference in migration rates within free-migration regime. The social magnet hypothesis is indeed confirmed (the first row) for Group A. The coefficient is negative and significant. That is, the generosity of the welfare state adversely

affects the skill difference of migration in the free-migration regime, capturing the market-based supply-side effect.

The fiscal burden hypothesis, relates to the considerations of the host country's voters in policy-controlled migration regimes, is also confirmed. As suggested in the Theory section, the difference between the differential effect of benefits across the controlled and free-migration regimes should be positive. Indeed, the coefficient is positive and significantly different than the corresponding coefficient in the free migration regime (second row) for DCs (Group B). That is, the effect of the generosity of the welfare state on the skill composition of migrants is positively affected by the migration policy of the host countries. However the coefficient is not always significant for LDCs (Group C) suggesting our a priori concern about the endogeneity of welfare 
benefits. The inclusion of the returns to skill proxy measured by the skilledunskilled native labor stocks ratio in the host country in 1990 (column 2), or (column 3) the skilled-unskilled wage differential does not have much of an effect on the magnitude or significance of the coefficients of the welfare-state benefits. Similar results are obtained when using migration rates that are adjusted for quality of education, i.e. $E Q_{s} / E Q_{h}$ (see Table 4).

Turing to Table 5 which presents the IV estimates, it is important to note that the first stage Cragg-Donald F-statistics show that our instruments are not subject to weak instrument concerns. Indeed, we find evidence in favor of the magnet hypothesis, i.e. a negative and significant effect of welfarestate benefits on the skill composition of immigrants within a free-migration regime. The generosity of the welfare-state adversely affects the skill composition of migrants in the free-migration regime. As predicted, using the IV, we find the effect of the generosity of the welfare-state on the skill composition of migrants under the policy-controlled migration regime is positive, for both developed (Group B, Column 1) and developing countries (Group C, Column 4). This result also holds after controlling for all the other push-pull factors (Columns 2 and 3 for DCs and Columns 5 and 6 for LDCs). Recall that in the case of the OLS estimates LDC coefficients were not significant.

Turning to the restricted - migration regime we confirm the fiscal burden hypothesis for both developed and developing source countries. That is $\beta_{3}$ is positive and significant. In this regression, unadjusted for educational quality, the effect of the generosity tends to be larger for DCs compared to LDCs. In terms of magnitude, our results suggest that $1 \%$ increase in welfarestate benefit per capita spending changes the skill difference in migration 
rates in favour of skilled migrants for LDCs by about $2.0 \%$ and for DCs migrants by about $3.5 \%$.

Table 6 presents IV estimates using migration rates that are adjusted for quality of education. It is clear that our previous results pertaining to the negative effect of the welfare-state benefits on the skill difference in migration rates of immigrants within the free-migration regime hold. A positive effect within the restricted-migration regime for both DCs and LDCs hold after adjusting for the quality of education also confirm the fiscal burden effect. Furthermore controlling for quality of education strengthens the positive effects of the skill composition of LDCs, and hardly changes the estimate for DCs. We find that a $1 \%$ increase in welfare-state benefit spending would improve the skill composition of LDCs migrants by around $2.5 \%$ and of DCs migrants by around $3.4 \%$.

There are potentially several reasons for the difference in effect of the welfare spending on migrant skill composition between LDCs and DCs. First, it could be because policies controlling for immigration typically ignore differences in educational quality even though they generate different fiscal burdens. Second, it could also be due to family re-unification and refugee immigration policies adopted by EU countries- which are imperfectly measured in our analysis.

Turning to the other control variables, the variables capturing immigration policies adopted in the EU have negative effects, as expected: the share of refugees in total migrants in the host country in 1990 and the total migrant stock from the source country in the host country in 1990, have negative but insignificant effects. However, for LDCs, the total stock of migrants in 1990 
has a negative and significant effect which can be interpreted as a diaspora effect as in Beine et al (2011).

Finally, examining the differential effect of returns to skills under the two policy regimes, we find, interestingly, that inequality in the source country has a negative significant effect on the skill mix of migrants from both LDCs and DCs under restrictive migration and a positive effect under free migration. Both are consistent with the Roy-Borjas hypothesis. As for the relative returns to skill in the host, the higher the high-low labor ratio, the lower are the returns to skill and the lower are the skill difference in migration rates. However, this effect seems to be significant only for DCs. Indeed, using the wage differential between high- and low- skilled in the host country, which is a better measure of returns to skills, shows that there is a positive relationship between the returns to skill and the skill composition of migrants for both DCs and LDCs under controlled migration, and no differential effect for free migration. Thus overall, the results indicate that even after controlling for returns to skills, the generosity of the welfare state matters for the skill composition of immigrants.

\subsection{Specification $1 b$}

Examining the estimates from the second specification 1b associated with the flow dependent variable, Table 7 shows that for both DCs and LDCs, the social magnet hypothesis holds, and that the findings support the fiscal burden hypothesis. When adjusting for the flows by Relative Education

Quality, again the estimates for LDCs are affected more than those for DCs, and our previous results are all upheld. 


\subsection{Robustness Checks}

Returning to specification 1a, we provide in this sub-section a few robustness checks by using different methods to adjust for education quality and using different measure for benefits as follow.

\subsubsection{Alternative Educational Quality Adjustments}

Using Hanushek and Wossemann (2009) educational quality index, we adjust the migration rates by interacting them with $E Q_{s}$ as shown in panel 1 of Table 8. Similarly using the Hanushek and Wossemann (2009) educational quality index, we weight migration rates with $E Q_{s}$ in panel 2 of Table 8 . In both cases our previous results are robust.

\subsubsection{An Alternative Measure for the Generosity of the Welfare State}

Finally, we check whether our measure of the welfare generosity is robust.

In Table 8, panel 3, we replace the level of benefits per capita measure by social spending as percent of GDP. Again, we find the generosity of the welfare state adversely affects the skill difference of migration in the freemigration regime, capturing the market-based supply-side effect, whilst the fiscal burden hypothesis, capturing the considerations of the host country's voters in policy-controlled migration regimes, is also confirmed. 


\section{Conclusion}

In a free-migration regime, a typical welfare state with relatively abundant capital and high total factor productivity (implying relatively high wages for all skill levels) attracts both unskilled and skilled migrants. On the other hand, the generosity of the welfare state attracts unskilled (poor) migrants, as they are net beneficiaries of the generous welfare state. In contrast, potential skilled (rich) migrants are deterred by the generosity of the welfare state. Thus the generosity of the welfare state shifts the migrant skill composition towards the unskilled. In the restricted-migration regime, these same considerations lead voters to favor skilled migration. Voters are motivated by : how migration affects their wages, and how it bears on the finances of the welfare state. Typically, unskilled migration depresses the unskilled wage and boosts the skilled wage. The opposite occurs with skilled migration. From a public finance point of view, native-born voters of all skills would therefore opt for the skilled to come and for the unskilled to stay away to mitigate the fiscal burden.

We utilize the free labor movement within EUR (the EU, Norway and Switzerland) and the restricted movement from outside of the EUR to compare the free migration regime to the restricted migration regime. We find strong support for the "magnet hypothesis" under the free-migration regime, and the "fiscal burden hypothesis" under the restricted-migration regime even after controlling for differences in returns to skills in source and host countries.

Our findings highlight the importance of controlling for educational quality when studying high skilled migration from LDCs. In addition, it is clear 
from our analysis that immigration policies favoring high-skilled migrants do need to take into account educational quality. Hence, a selective immigration scheme based on years of education solely will not be as effective in identifying the high skilled as a point-based system where ability (for example, language ability and labour market experience) are considered. Another important implication of our findings is that under free-migration, the generosity of the welfare state acts as a magnet for the unskilled. This suggests that harmonizing the minimum welfare provision within the EU may be an attractive option to reduce the negative effect of the welfare state on the skill composition of EU immigrants under free-migration.

\section{References}

[1] Acemoglu, D., and Johnson, S. (2005), "Unbundling Institutions", Journal of Political Economy, 113(5), 949-95.

[2] Beine, M., F. Docquier and C. Ozden (2011), "Diasporas", Journal of Development Economics, 95(1), 30-41.

[3] Borjas, George J. (1987), "Self-Selection and the Earnings of Immigrants", American Economic Review, 77(4), 531-553.

[4] Borjas, George J. (1999), "Immigration and Welfare Magnets", Journal of Labor Economics 17(4), 607-37.

[5] Brueckner, Jan K. (2000), "Welfare Reform and the Race to the Bottom: Theory and Evidence", Southern Economic Journal, 66(3), 505. 
[6] Cohen, Alon, and Assaf Razin, (2009), "Skill Composition of Migration and Welfare State Generosity: Comparing Free and Policy-Controlled Migration Regimes," NBER Working Papers 14738.

[7] Coulombe, S. and J-F. Tremblay (2007), Migration and Skill Disparities across the Canadian Provinces, Regional Studies 43 (1), 5-18.

[8] De Giorgi, Giacomo and Michele Pellizzari (2006), "Welfare Migration in Europe and the Cost of a Harmonized Social Assistance," IZA Discussion Paper No. 2094.

[9] Docquier, Frederic and Abdeslam Marfouk (2006), "International Migration by Educational Attainment 1990-2000," in Caglar Ozden and Maurice Schiff (eds.), International Migration, Remittances ad the Brain Drain, McMillan and Palgrave: New York.

[10] Docquier, F. , S. Salomone and H. Rapoport (2011), Remittances, Migrants' Education and Immigration Policy: Theory and Evidence from Bilateral Data, mimeo, UC Louvain.

[11] Enchautegui, Maria E. (1997), "Welfare Payments and Other Determinants of Female Migration," Journal of Labor Economics, 15, 529.

[12] Gelbach, Jonah B. (2004), "The Life-cycle Welfare Migration Hypothesis: Evidence from the 1980 and 1990 Censuses," Journal of Political Economy 112, no. 5, 1091-1130.

[13] Grogger, J. and G. Hanson (2011), "Income maximization and the selection and sorting of international migrants," Journal of Development Economics, 95, 1: 42-57. 
[14] Hanushek, Eric and Ludger Woessmann (2009), "Do Better Schools Lead to More Growth? Cognitive Skills, Economic Outcomes, and Causation" NBER Working Papers 14738, 14633.

[15] Khoudour-Castéras, David (2008), "The Impact of Bismarck's Social Legislation on German Emigration Before World War I", Journal of Economic History 68, 221-243..

[16] Levine, Phillip B. and David J. Zimmerman (1999), "An Empirical Analysis of the Welfare Magnet Debate Using the NLSY", Journal of Population Economics, 12(3), 391.

[17] McKinnish, Terra (2007), "Welfare-Induced Migration at State Borders: New Evidence from Micro-Data" Journal of Public Economics, 91, 437..

[18] Razin, Assaf, Efraim Sadka and Benjarong Suwankiri (2011), Migration and the Welfare State: Political Economy Policy Formation, the MIT Press. 
Table 1: Immigration and Aggregate Social Spending

\begin{tabular}{|c|c|c|c|}
\hline Country of Immigration & $\begin{array}{c}\text { Low Education as \% } \\
\text { of total Immigration } \\
\text { in } 2000^{1}\end{array}$ & $\begin{array}{c}\text { High Education as \% } \\
\text { of total Immigration } \\
\text { in } 2000^{1}\end{array}$ & $\begin{array}{c}\text { Social expenditure } \\
\text { as \% GDP: } \\
\text { average 1980-1995 }\end{array}$ \\
\hline Austria & 47.5 & 12.7 & 24.10 \\
\hline Belgium & 65.7 & 18.3 & 25.18 \\
\hline Denmark & 44.8 & 17.3 & 25.51 \\
\hline Finland & 48.7 & 23.8 & 23.96 \\
\hline France & 74.6 & 16.4 & 25.03 \\
\hline Germany & 65.9 & 21.8 & 23.28 \\
\hline Greece & 44.5 & 15 & 15.01 \\
\hline Ireland & 13.6 & 41.1 & 17.14 \\
\hline Italy & 52.9 & 15.4 & 19.66 \\
\hline Netherlands & 50.2 & 22 & 24.88 \\
\hline Norway & 22 & 28.7 & 20.05 \\
\hline Portugal & 59.7 & 18.6 & 12.25 \\
\hline Spain & 28.7 & 18.5 & 18.67 \\
\hline Sweden & 34.1 & 25.7 & 29.73 \\
\hline Switzerland & 54.9 & 18.6 & 14.85 \\
\hline UK & 34.1 & 34.9 & 18.16 \\
\hline Average EUR & 46.37 & 21.8 & 21.09 \\
\hline Australia & 35.3 & 40.3 & 12.93 \\
\hline Canada & 29.6 & 58.8 & 16.91 \\
\hline USA & 37.9 & 42.7 & 17.50 \\
\hline Average AUS, CAN\& US & 34.27 & 47.27 & 15.78 \\
\hline
\end{tabular}

Sources: ${ }^{1}$ Docquier and Marfouk (2006). ${ }^{2}$ OECD, Social Expenditure Database (SOCX). 
Table 2: Skill-Difference in Migration Rates and Welfare State Generosity

$\begin{array}{cccc}\text { Host Country } & \begin{array}{c}\text { Skill Difference } \\ \text { in migration } \\ \text { rates in } 2000\end{array} & \begin{array}{c}\text { Social } \\ \text { expenditure } \\ \text { as \% GDP }\end{array} & \begin{array}{c}\text { Social } \\ \text { expenditure } \\ \text { Per capita }^{2}\end{array}\end{array}$

$(\%)^{1}$

\section{Sweden}

Immigration from EUR

Immigration from non-EUR DC

Immigration from LDC

The Netherlands

Immigration from EUR

Immigration from non-EUR DC

Immigration from LDC

UK

Immigration from EUR

Immigration from non-EUR DC

Immigration from LDC

Spain

Immigration from EUR

Immigration from non-EUR DC Immigration from LDC

EUR

Immigration from EUR

Immigration from non-EUR DC
28.80

$-30.62$

4.32

67.67

25.40

$-3.89$

6.38

49.32

36.81

70.03

91.74

47.91

68.86

63.69

15.77

59.36

65.60

18.23

17.47
5124

3767

1567

1475

Immigration from LDC

Notes: Skill difference in migration rates denotes high skilled migration rate minus unskilled migration rate. Social expenditure as \% GDP (average for 1980-90); Social expenditure per capita is in PPP 1990 US dollars, average for 1974-90.

Sources: ${ }^{1}$ Authors' calculations based on Docquier and Marfouk (2006). ${ }^{2}$ OECD, Social Expenditure Database (SOCX). 
Table 3: OLS Estimates with Lagged Dependent Variable

Dependent Variable: Skill Difference in Migration Rates in 2000

\begin{tabular}{|c|c|c|c|c|c|c|}
\hline \multirow[b]{2}{*}{ Welfare generosity } & \multicolumn{3}{|c|}{$\begin{array}{l}\text { EUR \& DC } \\
\text { to EUR }\end{array}$} & \multicolumn{3}{|c|}{$\begin{array}{l}\text { EUR \& LDC } \\
\text { to EUR }\end{array}$} \\
\hline & & & & & & \\
\hline $\begin{array}{l}\text { benefits per capita (logs) } \\
1974-90 \text { (host) }\end{array}$ & $\begin{array}{l}-0.110 \\
(0.057)^{*}\end{array}$ & $\begin{array}{l}-0.112 \\
(0.056)^{* *}\end{array}$ & $\begin{array}{l}-0.116 \\
(0.047)^{* *}\end{array}$ & $\begin{array}{l}-0.115 \\
(0.056)^{* *}\end{array}$ & $\begin{array}{l}-0.136 \\
(0.053)^{* *}\end{array}$ & $\begin{array}{l}-0.131 \\
(0.047)^{* * *}\end{array}$ \\
\hline $\begin{array}{l}\text { benefits per capita (logs) } \\
1974-90 \text { (host) X R }\end{array}$ & $\begin{array}{l}0.113 \\
(0.053)^{* *}\end{array}$ & $\begin{array}{l}0.137 \\
(0.064)^{* *}\end{array}$ & $\begin{array}{l}0.132 \\
(0.055)^{* *}\end{array}$ & $\begin{array}{l}0.102 \\
(0.065)\end{array}$ & $\begin{array}{l}0.101 \\
(0.079)\end{array}$ & $\begin{array}{l}0.110 \\
(0.066)^{*}\end{array}$ \\
\hline \multicolumn{7}{|l|}{ Lagged migration rates } \\
\hline $\begin{array}{l}\text { low-skilled migration rate } \\
1990\end{array}$ & $\begin{array}{l}-0.719 \\
(0.133)^{* * *}\end{array}$ & $\begin{array}{l}-0.719 \\
(0.129)^{* * *}\end{array}$ & $\begin{array}{l}-0.710 \\
(0.140)^{* * *}\end{array}$ & $\begin{array}{l}-0.612 \\
(0.128)^{* * *}\end{array}$ & $\begin{array}{l}-0.611 \\
(0.129)^{* * *}\end{array}$ & $\begin{array}{l}-0.609 \\
(0.137)^{* * *}\end{array}$ \\
\hline $\begin{array}{l}\text { low-skilled migration rate } \\
1990 \times \mathrm{R}\end{array}$ & $\begin{array}{l}1.723 \\
(0.173) * * *\end{array}$ & $\begin{array}{l}1.751 \\
(0.169) * * *\end{array}$ & $\begin{array}{l}1.723 \\
(0.171) * * *\end{array}$ & $\begin{array}{l}0.278 \\
(0.196)\end{array}$ & $\begin{array}{l}0.560 \\
(0.234)^{* *}\end{array}$ & $\begin{array}{l}0.552 \\
(0.226)^{* *}\end{array}$ \\
\hline $\begin{array}{l}\text { high-skilled migration rate } \\
1990\end{array}$ & $\begin{array}{l}1.062 \\
(0.150)^{* * *}\end{array}$ & $\begin{array}{l}1.061 \\
(0.147)^{* * *}\end{array}$ & $\begin{array}{l}1.049 \\
(0.155)^{* * *}\end{array}$ & $\begin{array}{l}0.963 \\
(0.145) * * *\end{array}$ & $\begin{array}{l}0.959 \\
(0.146)^{* * *} \\
\end{array}$ & $\begin{array}{l}0.957 \\
(0.153)^{* * *}\end{array}$ \\
\hline $\begin{array}{l}\text { high-skilled migration rate } \\
1990 \times \text { R }\end{array}$ & $\begin{array}{l}-0.725 \\
(0.149)^{* * *}\end{array}$ & $\begin{array}{l}-0.726 \\
(0.144)^{* * *}\end{array}$ & $\begin{array}{l}-0.712 \\
(0.151)^{* * *}\end{array}$ & $\begin{array}{l}-0.481 \\
(0.157)^{* * *}\end{array}$ & $\begin{array}{l}-0.627 \\
(0.170)^{* * *} \\
\end{array}$ & $\begin{array}{l}-0.623 \\
(0.173)^{* * *} \\
\end{array}$ \\
\hline \multicolumn{7}{|l|}{ Returns to skills } \\
\hline $\begin{array}{l}\text { high-low labor ratio in } \\
1990 \text { - (host) }\end{array}$ & & $\begin{array}{l}-0.484 \\
(0.237)^{* *}\end{array}$ & & & $\begin{array}{l}0.309 \\
(0.326) \\
\end{array}$ & \\
\hline $\begin{array}{l}\text { high-low labor ratio in } \\
1990 \text { (host) X F }\end{array}$ & & $\begin{array}{l}0.309 \\
(0.500)\end{array}$ & & & $\begin{array}{l}0.019 \\
(0.656)\end{array}$ & \\
\hline $\begin{array}{l}\text { high-low wage diff. in } \\
1995 \text { (host) }\end{array}$ & & & $\begin{array}{l}0.003 \\
(0.002)\end{array}$ & & & $\begin{array}{l}0.001 \\
(0.003)\end{array}$ \\
\hline $\begin{array}{l}\text { high-low wage diff. in } \\
1995 \text { - (host) X F }\end{array}$ & & & $\begin{array}{l}-0.007 \\
(0.003) * *\end{array}$ & & & $\begin{array}{l}-0.005 \\
(0.003)^{*}\end{array}$ \\
\hline Gini in 1990 (source) & & $\begin{array}{l}0.012 \\
(0.004) * * *\end{array}$ & $\begin{array}{l}0.013 \\
(0.004) * * *\end{array}$ & & $\begin{array}{l}0.011 \\
(0.004)^{* *}\end{array}$ & $\begin{array}{l}0.011 \\
(0.005)^{* *}\end{array}$ \\
\hline Gini in 1990 (source) X R & & $\begin{array}{l}-0.012 \\
(0.005) * * *\end{array}$ & $\begin{array}{l}-0.014 \\
(0.005)^{* * *}\end{array}$ & & $\begin{array}{l}-0.010 \\
(0.005)^{* *}\end{array}$ & $\begin{array}{l}-0.010 \\
(0.005)^{*}\end{array}$ \\
\hline $\begin{array}{l}\text { high-low unemp. rate diff. } \\
\text { in } 1990 \text { (host) }\end{array}$ & & $\begin{array}{l}0.002 \\
(0.002)\end{array}$ & $\begin{array}{l}0.001 \\
(0.002)\end{array}$ & & $\begin{array}{l}0.003 \\
(0.002)\end{array}$ & $\begin{array}{l}0.006 \\
(0.002)\end{array}$ \\
\hline $\begin{array}{l}\text { high-low unemp. rate diff. } \\
\text { in } 1990 \text { - (host) X F }\end{array}$ & & $\begin{array}{l}-0.002 \\
(0.004) \\
\end{array}$ & $\begin{array}{l}-0.004 \\
(0.004) \\
\end{array}$ & & $\begin{array}{l}-0.005 \\
(0.005) \\
\end{array}$ & $\begin{array}{l}-0.008 \\
(0.005)^{*}\end{array}$ \\
\hline \multicolumn{7}{|l|}{ Immigration policies } \\
\hline $\begin{array}{l}\text { Total migrant stock } \\
\text { in } 1990\end{array}$ & $\begin{array}{l}-0.001 \\
(0.001)\end{array}$ & $\begin{array}{l}-0.001 \\
(0.001)\end{array}$ & $\begin{array}{l}-0.001 \\
(0.001)\end{array}$ & $\begin{array}{l}-0.002 \\
(0.001)^{* * *}\end{array}$ & $\begin{array}{l}-0.002 \\
(0.001)^{* *}\end{array}$ & $\begin{array}{l}-0.002 \\
(0.001)^{* *}\end{array}$ \\
\hline Share of refugees in 1990 & $\begin{array}{l}-2.079 \\
(2.803)\end{array}$ & $\begin{array}{l}-1.023 \\
(3.237)\end{array}$ & $\begin{array}{l}-3.904 \\
(3.403)\end{array}$ & $\begin{array}{l}-0.238 \\
(2.145)\end{array}$ & $\begin{array}{l}-1.945 \\
(2.477)\end{array}$ & $\begin{array}{l}-1.297 \\
(3.007)\end{array}$ \\
\hline Observations & 384 & 384 & 360 & 601 & 570 & 534 \\
\hline R-squared & 0.864 & 0.870 & 0.874 & 0.832 & 0.809 & 0.814 \\
\hline
\end{tabular}

Notes: F=Free migration; $\mathrm{R}=$ Restricted migration. Regressions include log distance, dummy for same language in host and source, strong dummy between host and source, \& real GDP per capita in host and in source countries. Robust standard errors in parentheses; * significant at 10\%; ** significant at 5\%; *** significant at $1 \%$. 
Table 4: OLS Estimates Using Migration Rates Adjusted by Relative Educational Quality Dependent Variable: Skill Difference in Migration (REQ) Rates in 2000

\begin{tabular}{|c|c|c|c|c|c|c|}
\hline \multirow[b]{2}{*}{ Welfare generosity } & \multicolumn{3}{|c|}{$\begin{array}{l}\text { EUR \& DC } \\
\text { to EUR }\end{array}$} & \multicolumn{3}{|c|}{$\begin{array}{c}\text { EUR \& LDC } \\
\text { to EUR }\end{array}$} \\
\hline & & & & & & \\
\hline $\begin{array}{l}\text { benefits per capita } \\
\text { (logs) 1974-90 (host) }\end{array}$ & $\begin{array}{l}-0.105 \\
(0.052)^{* *}\end{array}$ & $\begin{array}{l}-0.115 \\
(0.049)^{* *}\end{array}$ & $\begin{array}{l}-0.109 \\
(0.042)^{* *}\end{array}$ & $\begin{array}{l}-0.111 \\
(0.051)^{* *}\end{array}$ & $\begin{array}{l}-0.116 \\
(0.054)^{* *}\end{array}$ & $\begin{array}{l}-0.138 \\
(0.054)^{* *}\end{array}$ \\
\hline $\begin{array}{l}\text { benefits per capita (logs) } \\
1974-90 \text { (host) X R }\end{array}$ & $\begin{array}{l}0.115 \\
(0.053)^{* *}\end{array}$ & $\begin{array}{l}0.139 \\
(0.062)^{* *}\end{array}$ & $\begin{array}{l}0.135 \\
(0.054)^{* *}\end{array}$ & $\begin{array}{l}0.104 \\
(0.059)^{*}\end{array}$ & $\begin{array}{l}0.111 \\
(0.070)\end{array}$ & $\begin{array}{l}0.132 \\
(0.062)^{* *}\end{array}$ \\
\hline \multicolumn{7}{|l|}{ Lagged migration rates } \\
\hline $\begin{array}{l}\text { low-skilled migration } \\
\text { rate (REQ) } 1990\end{array}$ & $\begin{array}{l}-0.697 \\
(0.151)^{* * *}\end{array}$ & $\begin{array}{l}-0.695 \\
(0.149)^{* * *}\end{array}$ & $\begin{array}{l}-0.686 \\
(0.160)^{* * *}\end{array}$ & $\begin{array}{l}-0.681 \\
(0.156)^{* * *}\end{array}$ & $\begin{array}{l}-0.595 \\
(0.143)^{* * *}\end{array}$ & $\begin{array}{l}-0.578 \\
(0.150)^{* * *}\end{array}$ \\
\hline $\begin{array}{l}\text { low-skilled migration } \\
\text { rate (REQ) } 1990 \times \mathrm{R}\end{array}$ & $\begin{array}{l}1.711 \\
(0.175) * * *\end{array}$ & $\begin{array}{l}1.738 \\
(0.172)^{* * *}\end{array}$ & $\begin{array}{l}1.713 \\
(0.174) * * *\end{array}$ & $\begin{array}{l}0.715 \\
(0.295)^{* *}\end{array}$ & $\begin{array}{l}0.576 \\
(0.217) * * *\end{array}$ & $\begin{array}{l}0.314 \\
(0.208)\end{array}$ \\
\hline $\begin{array}{l}\text { high-skilled migration } \\
\text { rate (REQ) } 1990\end{array}$ & $\begin{array}{l}1.037 \\
(0.169)^{* * *}\end{array}$ & $\begin{array}{l}1.033 \\
(0.168)^{* * *} \\
\end{array}$ & $\begin{array}{l}1.022 \\
(0.176)^{* * *}\end{array}$ & $\begin{array}{l}1.011 \\
(0.175)^{* * *}\end{array}$ & $\begin{array}{l}0.937 \\
(0.162)^{* * *}\end{array}$ & $\begin{array}{l}0.920 \\
(0.167)^{* * *}\end{array}$ \\
\hline $\begin{array}{l}\text { high-skilled migration } \\
\text { rate (REQ) } 1990 \text { x R }\end{array}$ & $\begin{array}{l}-0.702 \\
(0.167)^{* * *}\end{array}$ & $\begin{array}{l}-0.702 \\
(0.164)^{* * *} \\
\end{array}$ & $\begin{array}{l}-0.688 \\
(0.171)^{* * *}\end{array}$ & $\begin{array}{l}-0.584 \\
(0.194)^{* * *}\end{array}$ & $\begin{array}{l}-0.637 \\
(0.175)^{* * *}\end{array}$ & $\begin{array}{l}-0.468 \\
(0.178)^{* * *}\end{array}$ \\
\hline \multicolumn{7}{|l|}{ Returns to skills } \\
\hline $\begin{array}{l}\text { high-low labor ratio in } \\
1990 \text { - (host) }\end{array}$ & & $\begin{array}{l}-0.482 \\
(0.234)^{* *}\end{array}$ & & & $\begin{array}{l}0.205 \\
(0.302) \\
\end{array}$ & \\
\hline $\begin{array}{l}\text { high-low labor ratio in } \\
1990 \text { (host) X F }\end{array}$ & & $\begin{array}{l}0.325 \\
(0.482)\end{array}$ & & & $\begin{array}{l}0.043 \\
(0.571)\end{array}$ & \\
\hline $\begin{array}{l}\text { high-low wage diff. in } \\
1995 \text { - (host) }\end{array}$ & & & $\begin{array}{l}0.002 \\
(0.002)\end{array}$ & & & $\begin{array}{l}0.003 \\
(0.003)\end{array}$ \\
\hline $\begin{array}{l}\text { high-low wage diff. in } \\
1995 \text { (host) X R }\end{array}$ & & & $\begin{array}{l}-0.007 \\
(0.003)^{* *}\end{array}$ & & & $\begin{array}{l}-0.006 \\
(0.003) *\end{array}$ \\
\hline Gini in 1990 (source) & & $\begin{array}{l}0.013 \\
(0.004)^{* * *}\end{array}$ & $\begin{array}{l}0.014 \\
(0.004) * * *\end{array}$ & & $\begin{array}{l}0.011 \\
(0.004) * * *\end{array}$ & $\begin{array}{l}0.013 \\
(0.005) * * *\end{array}$ \\
\hline $\begin{array}{l}\text { Gini in } 1990 \text { (source) } \\
\text { X R }\end{array}$ & & $\begin{array}{l}-0.013 \\
(0.005)^{* * *}\end{array}$ & $\begin{array}{l}-0.014 \\
(0.005)^{* * *}\end{array}$ & & $\begin{array}{l}-0.011 \\
(0.005)^{* *}\end{array}$ & $\begin{array}{l}-0.011 \\
(0.005) * *\end{array}$ \\
\hline $\begin{array}{l}\text { high-low unemp. rate } \\
\text { diff. in } 1990 \text { - (host) } \\
\end{array}$ & & & $\begin{array}{l}0.001 \\
(0.002) \\
\end{array}$ & & $\begin{array}{l}0.001 \\
(0.002)\end{array}$ & $\begin{array}{l}0.006 \\
(0.004)\end{array}$ \\
\hline $\begin{array}{l}\text { high-low unemp. rate } \\
\text { diff. in } 1990 \text { (host) X F }\end{array}$ & & & $\begin{array}{l}-0.004 \\
(0.004)\end{array}$ & & $\begin{array}{l}-0.005 \\
(0.004)\end{array}$ & $\begin{array}{l}-0.009 \\
(0.005)^{*}\end{array}$ \\
\hline \multicolumn{7}{|l|}{ Immigration policies } \\
\hline $\begin{array}{l}\text { Total migrant stock } \\
\text { in } 1990\end{array}$ & $\begin{array}{l}-0.001 \\
(0.001)\end{array}$ & $\begin{array}{l}-0.001 \\
(0.001)\end{array}$ & $\begin{array}{l}-0.001 \\
(0.001)\end{array}$ & $\begin{array}{l}-0.001 \\
(0.001)\end{array}$ & $\begin{array}{l}-0.002 \\
(0.001)^{* * *}\end{array}$ & $\begin{array}{l}-0.002 \\
(0.001)^{* *}\end{array}$ \\
\hline $\begin{array}{l}\text { Share of refugees in } \\
1990\end{array}$ & $\begin{array}{l}-1.907 \\
(2.547)\end{array}$ & $\begin{array}{l}-1.168 \\
(3.230)\end{array}$ & $\begin{array}{l}-3.680 \\
(3.298)\end{array}$ & $\begin{array}{l}-0.672 \\
(1.983)\end{array}$ & $\begin{array}{l}-2.954 \\
(2.509)\end{array}$ & $\begin{array}{l}-1.497 \\
(3.081)\end{array}$ \\
\hline Observations & 384 & 384 & 360 & 569 & 569 & 533 \\
\hline R-squared & 0.861 & 0.867 & 0.871 & 0.842 & 0.816 & 0.835 \\
\hline
\end{tabular}

Notes: All the migration rates are adjusted for the quality of education by the relative education quality in source to host country, i.e. $R E Q=\left(E Q_{s} / E Q_{h}\right) ; \mathrm{F}=$ Free migration; $\mathrm{R}=$ Restricted migration. Regressions include log distance, dummy for same language in host and source, strong dummy between host and source, and real GDP per capita in host and in source countries.

Robust standard errors in parentheses; * significant at 10\%; ** significant at 5\%; *** significant at $1 \%$. 
Table 5: IV Estimates with Lagged Dependent Variable

Dependent Variable: Skill Difference in Migration Rates in 2000

\begin{tabular}{|c|c|c|c|c|c|c|}
\hline & \multicolumn{3}{|c|}{$\begin{array}{l}\text { EUR \& DC } \\
\text { to EUR }\end{array}$} & \multicolumn{3}{|c|}{$\begin{array}{l}\text { EUR \& LDC } \\
\text { to EUR }\end{array}$} \\
\hline \multicolumn{7}{|l|}{ Welfare generosity } \\
\hline $\begin{array}{l}\text { Fitted benefits per capita } \\
\text { (logs) } 1974-90 \text { (host) }\end{array}$ & $\begin{array}{l}-0.157 \\
(0.081)^{*}\end{array}$ & $\begin{array}{l}-0.217 \\
(0.097)^{* *}\end{array}$ & $\begin{array}{l}-0.118 \\
(0.063)^{*}\end{array}$ & $\begin{array}{l}-0.181 \\
(0.080)^{* *}\end{array}$ & $\begin{array}{l}-0.180 \\
(0.089)^{* *}\end{array}$ & $\begin{array}{l}-0.154 \\
(0.070)^{* *}\end{array}$ \\
\hline $\begin{array}{l}\text { Fitted benefits per capita } \\
\text { (logs) } 1974-90 \text { (host) X R }\end{array}$ & $\begin{array}{l}0.270 \\
(0.089)^{* * *}\end{array}$ & $\begin{array}{l}0.261 \\
(0.099) * * *\end{array}$ & $\begin{array}{l}0.207 \\
(0.078) * * *\end{array}$ & $\begin{array}{l}0.198 \\
(0.088)^{* *}\end{array}$ & $\begin{array}{l}0.209 \\
(0.103)^{* *}\end{array}$ & $\begin{array}{l}0.161 \\
(0.083) *\end{array}$ \\
\hline \multicolumn{7}{|l|}{ Lagged migration rates } \\
\hline $\begin{array}{l}\text { low-skilled migration } \\
\text { rate } 1990\end{array}$ & $\begin{array}{l}-0.711 \\
(0.130)^{* * *}\end{array}$ & $\begin{array}{l}-0.711 \\
(0.125)^{* * *}\end{array}$ & $\begin{array}{l}-0.706 \\
(0.135) * * *\end{array}$ & $\begin{array}{l}-0.592 \\
(0.131)^{* * *}\end{array}$ & $\begin{array}{l}-0.581 \\
(0.131)^{* * *}\end{array}$ & $\begin{array}{l}-0.581 \\
(0.137)^{* * *}\end{array}$ \\
\hline $\begin{array}{l}\text { low-skilled migration } \\
\text { rate } 1990 \times \mathrm{R}\end{array}$ & $\begin{array}{l}1.774 \\
(0.171)^{* * *}\end{array}$ & $\begin{array}{l}1.775 \\
(0.166)^{* * *}\end{array}$ & $\begin{array}{l}1.752 \\
(0.169)^{* * *}\end{array}$ & $\begin{array}{l}0.563 \\
(0.229)^{* *}\end{array}$ & $\begin{array}{l}0.556 \\
(0.229)^{* *}\end{array}$ & $\begin{array}{l}0.562 \\
(0.221)^{* *}\end{array}$ \\
\hline $\begin{array}{l}\text { high-skilled migration } \\
\text { rate } 1990\end{array}$ & $\begin{array}{l}1.055 \\
(0.147)^{* * *}\end{array}$ & $\begin{array}{l}1.052 \\
(0.142)^{* * *}\end{array}$ & $\begin{array}{l}1.046 \\
(0.150) * * *\end{array}$ & $\begin{array}{l}0.944 \\
(0.148)^{* * *}\end{array}$ & $\begin{array}{l}0.931 \\
(0.148) * * *\end{array}$ & $\begin{array}{l}0.933 \\
(0.152) * * *\end{array}$ \\
\hline $\begin{array}{l}\text { high-skilled migration } \\
\text { rate } 1990 \times \mathrm{R}\end{array}$ & $\begin{array}{l}-0.726 \\
(0.147)^{* * *}\end{array}$ & $\begin{array}{l}-0.722 \\
(0.141)^{* * *}\end{array}$ & $\begin{array}{l}-0.713 \\
(0.148) * * *\end{array}$ & $\begin{array}{l}-0.627 \\
(0.166)^{* * *}\end{array}$ & $\begin{array}{l}-0.611 \\
(0.168)^{* * *}\end{array}$ & $\begin{array}{l}-0.618 \\
(0.168)^{* * *}\end{array}$ \\
\hline \multicolumn{7}{|l|}{ Returns to skills } \\
\hline $\begin{array}{l}\text { high-low labor ratio in } \\
1990 \text { - (host) }\end{array}$ & & $\begin{array}{l}-1.455 \\
(0.541)^{* * *}\end{array}$ & & & $\begin{array}{l}0.060 \\
(0.458)\end{array}$ & \\
\hline $\begin{array}{l}\text { high-low labor ratio in } \\
1990 \text { (host ) X F }\end{array}$ & & $\begin{array}{l}0.794 \\
(0.548) \\
\end{array}$ & & & $\begin{array}{l}0.522 \\
(0.690) \\
\end{array}$ & \\
\hline $\begin{array}{l}\text { high-low wage diff. in } \\
1995 \text { (host) }\end{array}$ & & & $\begin{array}{l}0.003 \\
(0.002)\end{array}$ & & & $\begin{array}{l}0.003 \\
(0.003)\end{array}$ \\
\hline $\begin{array}{l}\text { high-low wage diff. in } \\
1995 \text { - (host) X F }\end{array}$ & & & $\begin{array}{l}-0.008 \\
(0.003)^{* * *}\end{array}$ & & & $\begin{array}{l}-0.006 \\
(0.003)^{*}\end{array}$ \\
\hline Gini in 1990 (source) & & $\begin{array}{l}0.012 \\
(0.004)^{* * *}\end{array}$ & $\begin{array}{l}0.012 \\
(0.004)^{* * *}\end{array}$ & & $\begin{array}{l}0.011 \\
(0.004) * * *\end{array}$ & $\begin{array}{l}0.011 \\
(0.004)^{* *}\end{array}$ \\
\hline Gini in 1990 (source) X R & & $\begin{array}{l}-0.013 \\
(0.005)^{* * *} \\
\end{array}$ & $\begin{array}{l}-0.015 \\
(0.005)^{* * *}\end{array}$ & & $\begin{array}{l}-0.010 \\
(0.005)^{* *} \\
\end{array}$ & $\begin{array}{l}-0.010 \\
(0.005)^{* *} \\
\end{array}$ \\
\hline $\begin{array}{l}\text { high-low unemp. rate } \\
\text { diff. } 1990 \text { (host) }\end{array}$ & & $\begin{array}{l}0.011 \\
(0.005)\end{array}$ & $\begin{array}{l}-0.000 \\
(0.002)\end{array}$ & & $\begin{array}{l}0.005 \\
(0.003)\end{array}$ & $\begin{array}{l}0.005 \\
(0.004)\end{array}$ \\
\hline $\begin{array}{l}\text { high-low unemp. rate } \\
\text { diff. } 1990 \text { - (host) X F }\end{array}$ & & $\begin{array}{l}-0.005 \\
(0.005) \\
\end{array}$ & $\begin{array}{l}-0.005 \\
(0.004) \\
\end{array}$ & & $\begin{array}{l}-0.008 \\
(0.006) \\
\end{array}$ & $\begin{array}{l}-0.008 \\
(0.005)^{*}\end{array}$ \\
\hline \multicolumn{7}{|l|}{ Immigration policies } \\
\hline $\begin{array}{l}\text { Total migrant stock } \\
\text { in } 1990\end{array}$ & $\begin{array}{l}-0.001 \\
(0.001) \\
\end{array}$ & $\begin{array}{l}-0.001 \\
(0.001) \\
\end{array}$ & $\begin{array}{l}-0.001 \\
(0.001) \\
\end{array}$ & $\begin{array}{l}-0.002 \\
(0.001)^{* * *}\end{array}$ & $\begin{array}{l}-0.003 \\
(0.001)^{* * *}\end{array}$ & $\begin{array}{l}-0.003 \\
(0.001)^{* *}\end{array}$ \\
\hline Share of refugees in 1990 & $\begin{array}{l}-2.470 \\
(3.174)\end{array}$ & $\begin{array}{l}0.827 \\
(3.803)\end{array}$ & $\begin{array}{l}-4.835 \\
(3.670) \\
\end{array}$ & $\begin{array}{l}-1.590 \\
(2.603)\end{array}$ & $\begin{array}{l}-2.990 \\
(2.827)\end{array}$ & $\begin{array}{l}-2.261 \\
(3.266) \\
\end{array}$ \\
\hline Cragg-Donald F- statistics & 49.46 & 54.34 & 103.01 & 86.23 & 98.44 & 159.12 \\
\hline Observations & 384 & 384 & 360 & 538 & 538 & 504 \\
\hline R-squared & 0.865 & 0.871 & 0.875 & 0.811 & 0.815 & 0.821 \\
\hline
\end{tabular}

Notes: F=Free migration; R=Restricted migration. Instrumented using legal origin dummies, and the interaction of legal origin dummies and R. Regressions include real GDP per capita growth rate in host, log distance, dummy for same language in host and source, strong dummy between host and source, and real GDP per capita in host and in source countries.

Robust standard errors in parentheses; * significant at 10\%; ** significant at 5\%; *** significant at $1 \%$. 
Table 6: IV Estimates with Lagged Dependent Variable and Adjusted by Relative Educational Quality (REQ)

Dependent Variable: Skill Difference in Migration Rates (REQ) in 2000

\begin{tabular}{|c|c|c|c|c|c|c|}
\hline \multirow[b]{2}{*}{ Welfare generosity } & \multicolumn{3}{|c|}{$\begin{array}{l}\text { EUR \& DC } \\
\text { to EUR }\end{array}$} & \multicolumn{3}{|c|}{$\begin{array}{l}\text { EUR \& LDC } \\
\text { to EUR }\end{array}$} \\
\hline & & & & & & \\
\hline $\begin{array}{l}\text { Fitted benefits per capita } \\
\text { (logs) } 1974-90 \text { (host) }\end{array}$ & $\begin{array}{l}-0.159 \\
(0.075)^{* *}\end{array}$ & $\begin{array}{l}-0.207 \\
(0.087)^{* *}\end{array}$ & $\begin{array}{l}-0.170 \\
(0.070) * *\end{array}$ & $\begin{array}{l}-0.175 \\
(0.076) * *\end{array}$ & $\begin{array}{l}-0.179 \\
(0.079) * *\end{array}$ & $\begin{array}{l}-0.178 \\
(0.064)^{* * *}\end{array}$ \\
\hline $\begin{array}{l}\text { Fitted benefits per capita } \\
\text { (logs) 1974-90 (host) X R }\end{array}$ & $\begin{array}{l}0.269 \\
(0.089)^{* * *}\end{array}$ & $\begin{array}{l}0.268 \\
(0.098)^{* * *}\end{array}$ & $\begin{array}{l}0.207 \\
(0.077)^{* * *}\end{array}$ & $\begin{array}{l}0.207 \\
(0.083)^{* *}\end{array}$ & $\begin{array}{l}0.218 \\
(0.102)^{* *}\end{array}$ & $\begin{array}{l}0.194 \\
(0.080)^{* *}\end{array}$ \\
\hline \multicolumn{7}{|l|}{ Lagged migration rates } \\
\hline $\begin{array}{l}\text { low-skilled migration } \\
\text { rate (REQ) } 1990\end{array}$ & $\begin{array}{l}-0.686 \\
(0.148) * * *\end{array}$ & $\begin{array}{l}-0.685 \\
(0.145)^{* * *}\end{array}$ & $\begin{array}{l}-0.678 \\
(0.155)^{* * *}\end{array}$ & $\begin{array}{l}-0.602 \\
(0.144)^{* * *}\end{array}$ & $\begin{array}{l}-0.665 \\
(0.154)^{* * *}\end{array}$ & $\begin{array}{l}-0.666 \\
(0.164)^{* * *}\end{array}$ \\
\hline $\begin{array}{l}\text { low-skilled migration } \\
\text { rate (REQ) } 1990 \times \mathrm{R}\end{array}$ & $\begin{array}{l}1.753 \\
(0.172)^{* * *}\end{array}$ & $\begin{array}{l}1.765 \\
(0.170)^{* * *}\end{array}$ & $\begin{array}{l}1.732 \\
(0.174) * * *\end{array}$ & $\begin{array}{l}0.553 \\
(0.212)^{* * *}\end{array}$ & $\begin{array}{l}0.694 \\
(0.290)^{* *}\end{array}$ & $\begin{array}{l}0.686 \\
(0.292)^{* *}\end{array}$ \\
\hline $\begin{array}{l}\text { high-skilled migration } \\
\text { rate (REQ) } 1990\end{array}$ & $\begin{array}{l}1.026 \\
(0.166)^{* * *}\end{array}$ & $\begin{array}{l}1.022 \\
(0.163)^{* * *}\end{array}$ & $\begin{array}{l}1.014 \\
(0.171)^{* * *}\end{array}$ & $\begin{array}{l}0.941 \\
(0.163)^{* * *}\end{array}$ & $\begin{array}{l}0.991 \\
(0.173)^{* * *}\end{array}$ & $\begin{array}{l}0.989 \\
(0.180)^{* * *}\end{array}$ \\
\hline $\begin{array}{l}\text { high-skilled migration } \\
\text { rate (REQ) } 1990 \text { x R }\end{array}$ & $\begin{array}{l}-0.698 \\
(0.164)^{* * *}\end{array}$ & $\begin{array}{l}-0.693 \\
(0.162)^{* * *}\end{array}$ & $\begin{array}{l}-0.684 \\
(0.168) * * *\end{array}$ & $\begin{array}{l}-0.632 \\
(0.173)^{* * *}\end{array}$ & $\begin{array}{l}-0.566 \\
(0.193) * * *\end{array}$ & $\begin{array}{l}-0.564 \\
(0.198)^{* * *}\end{array}$ \\
\hline \multicolumn{7}{|l|}{ Returns to skills } \\
\hline $\begin{array}{l}\text { high-low labor ratio in } \\
1990 \text { - (host) }\end{array}$ & & $\begin{array}{l}-1.192 \\
(0.358)^{* * *}\end{array}$ & & & $\begin{array}{l}0.075 \\
(0.386)\end{array}$ & \\
\hline $\begin{array}{l}\text { high-low labor ratio in } \\
1990 \text { (host) X F }\end{array}$ & & $\begin{array}{l}0.833 \\
(0.534)\end{array}$ & & & $\begin{array}{l}0.027 \\
(0.574)\end{array}$ & \\
\hline $\begin{array}{l}\text { high-low wage diff. in } \\
1995 \text { (host) }\end{array}$ & & & $\begin{array}{l}0.004 \\
(0.002)^{*}\end{array}$ & & & $\begin{array}{l}0.003 \\
(0.002)\end{array}$ \\
\hline $\begin{array}{l}\text { high-low wage diff. in } \\
1995 \text { - (host) X F }\end{array}$ & & & $\begin{array}{l}-0.007 \\
(0.003) * *\end{array}$ & & & $\begin{array}{l}-0.007 \\
(0.005)^{* *}\end{array}$ \\
\hline Gini in 1990 (source) & & $\begin{array}{l}0.012 \\
(0.004)^{* * *}\end{array}$ & $\begin{array}{l}0.013 \\
(0.004) * * *\end{array}$ & & $\begin{array}{l}0.012 \\
(0.004) * * *\end{array}$ & $\begin{array}{l}0.013 \\
(0.005) * * *\end{array}$ \\
\hline Gini in 1990 (source) X R & & $\begin{array}{l}-0.013 \\
(0.005)^{* * *}\end{array}$ & $\begin{array}{l}-0.015 \\
(0.005)^{* * *}\end{array}$ & & $\begin{array}{l}-0.012 \\
(0.004)^{* * *}\end{array}$ & $\begin{array}{l}-0.012 \\
(0.004)^{* * *}\end{array}$ \\
\hline $\begin{array}{l}\text { high-low unemp. rate diff. } \\
\text { in } 1990 \text { (host) }\end{array}$ & & $\begin{array}{l}0.008 \\
(0.003)^{* *}\end{array}$ & $\begin{array}{l}0.002 \\
(0.003)\end{array}$ & & $\begin{array}{l}0.003 \\
(0.003)\end{array}$ & $\begin{array}{l}0.006 \\
(0.004)\end{array}$ \\
\hline $\begin{array}{l}\text { high-low unemp. rate diff. } \\
\text { in } 1990 \text { - (host) X F }\end{array}$ & & $\begin{array}{l}-0.005 \\
(0.005)\end{array}$ & $\begin{array}{l}-0.005 \\
(0.004)\end{array}$ & & $\begin{array}{l}-0.008 \\
(0.005)\end{array}$ & $\begin{array}{l}-0.012 \\
(0.004)^{* * *}\end{array}$ \\
\hline \multicolumn{7}{|l|}{ Immigration policies } \\
\hline Total migrant stock in 1990 & $\begin{array}{l}-0.001 \\
(0.001)\end{array}$ & $\begin{array}{l}-0.001 \\
(0.001)\end{array}$ & $\begin{array}{l}-0.001 \\
(0.001)\end{array}$ & $\begin{array}{l}-0.002 \\
(0.001)^{* *}\end{array}$ & $\begin{array}{l}-0.001 \\
(0.001)\end{array}$ & $\begin{array}{l}-0.001 \\
(0.001)\end{array}$ \\
\hline Share of refugees in 1990 & $\begin{array}{l}-2.592 \\
(3.245)\end{array}$ & $\begin{array}{l}0.106 \\
(3.535) \\
\end{array}$ & $\begin{array}{l}-2.809 \\
(3.548)\end{array}$ & $\begin{array}{l}-1.768 \\
(2.476) \\
\end{array}$ & $\begin{array}{l}-1.694 \\
(2.571)\end{array}$ & $\begin{array}{l}-1.315 \\
(2.919)\end{array}$ \\
\hline Cragg-Donald F- statistics & 51.69 & 58.98 & 62.65 & 86.45 & 92.77 & 169.49 \\
\hline Observations & 384 & 384 & 360 & 538 & 569 & 533 \\
\hline R-squared & 0.863 & 0.867 & 0.871 & 0.805 & 0.830 & 0.835 \\
\hline
\end{tabular}

Notes: All the migration rates are adjusted for the quality of education by relative quality in source to host, i.e. $R E Q=\left(E Q_{s} / E Q_{h}\right), F=$ Free migration; $\mathrm{R}=$ Restricted migration. Instrumented using legal origin dummies, and the interaction of legal origin dummies and R. Regressions include real GDP per capita growth rate in host, log distance, dummy for same language in host and source, strong dummy between host and source, and real GDP per capita in host and in source countries.

Robust standard errors in parentheses; * significant at 10\%; ** significant at 5\%; *** significant at $1 \%$. 
Table 7: IV Estimates for Flows: Specification (1b)

\begin{tabular}{|l|c|c|}
\hline & \multicolumn{1}{|c|}{$\begin{array}{c}\text { EUR \& DC } \\
\text { to EUR }\end{array}$} & $\begin{array}{c}\text { EUR \& LDC } \\
\text { to EUR }\end{array}$ \\
\hline Dependent variable: Skill Difference Migration Rates: Flows (1990-2000) \\
\hline Welfare generosity & -0.571 & -0.292 \\
\hline Fitted benefits per capita & $(0.242)^{* *}$ & $(0.118)^{* *}$ \\
\hline (logs) 1974-90 (host) & 0.585 & 0.294 \\
\hline Fitted benefits per capita & $(0.280)^{* *}$ & $(0.156)^{*}$ \\
\hline (logs) 1974-90 (host) X R & \multicolumn{2}{|c|}{} \\
\hline \multicolumn{3}{|c|}{} \\
$\begin{array}{l}\text { Dependent variable: Skill Difference Migration Rates adjusted by Relative Educational Quality: Flows } \\
\text { (1990-2000) }\end{array}$ & \multicolumn{2}{|c|}{} \\
\hline Welfare generosity & -0.576 & -0.372 \\
\hline Fitted benefits per capita & $(0.248)^{* *}$ & $(0.181)^{* *}$ \\
\hline (logs) 1974-90 (host) & 0.598 & 0.393 \\
\hline Fitted benefits per capita & $(0.303)^{* *}$ & $(0.204)^{*}$ \\
\hline (logs) 1974-90 (host) X R &
\end{tabular}

Notes: Instrumented using legal origin dummies and the interaction of legal origin dummies and R. ${ }^{1}$ Both models have all controls as in Table 5, column 3 (6) for DCs (LDCs). ${ }^{2}$ Both models have all controls as in Table 6, column 3 (6) for DCs (LDCs). Robust standard errors in parentheses; * significant at 10\%; ** significant at 5\%; *** significant at $1 \%$.

Table 8: IV Estimates: Robustness Analysis

\begin{tabular}{|c|c|c|}
\hline & $\begin{array}{c}\text { EUR \& DC } \\
\text { to EUR }\end{array}$ & $\begin{array}{l}\text { EUR \& LDC } \\
\text { to EUR }\end{array}$ \\
\hline \multicolumn{3}{|c|}{ Alternatives Adjustment for Education Quality } \\
\hline \multicolumn{3}{|c|}{ 1. Dependent variable: Skill Difference Migration Rates, interacted by Source Country Educational Quality } \\
\hline \multicolumn{3}{|l|}{ Welfare generosity } \\
\hline $\begin{array}{l}\text { Fitted benefits per capita } \\
\text { (logs) } 1974-90 \text { (host) }\end{array}$ & $\begin{array}{c}-0.860 \\
(0.358)^{* *}\end{array}$ & $\begin{array}{c}-0.905 \\
(0.324)^{* * *}\end{array}$ \\
\hline $\begin{array}{l}\text { Fitted benefits per capita } \\
\text { (logs) 1974-90 (host) X R }\end{array}$ & $\begin{array}{c}0.904 \\
(0.400)^{* *} \\
\end{array}$ & $\begin{array}{c}0.970 \\
(0.402)^{* *} \\
\end{array}$ \\
\hline \multicolumn{3}{|c|}{ 2. Dependent variable: Skill Difference Migration Rates, weighted Source Country by Education Quality ${ }^{2}$} \\
\hline \multicolumn{3}{|l|}{ Welfare generosity } \\
\hline $\begin{array}{l}\text { Fitted benefits per capita } \\
\text { (logs) } 1974-90 \text { (host) }\end{array}$ & $\begin{array}{c}-0.035 \\
(0.016)^{* *}\end{array}$ & $\begin{array}{c}-0.037 \\
(0.014)^{* * *}\end{array}$ \\
\hline $\begin{array}{l}\text { Fitted benefits per capita } \\
\text { (logs) } 1974-90 \text { (host) X R }\end{array}$ & $\begin{array}{c}0.038 \\
(0.0174)^{* *}\end{array}$ & $\begin{array}{c}0.039 \\
(0.021)^{*}\end{array}$ \\
\hline \multicolumn{3}{|l|}{ Alternative measure for Benefits } \\
\hline \multicolumn{3}{|c|}{ 3. Dependent variable: Skill Difference Migration Rates ${ }^{3}$} \\
\hline \multicolumn{3}{|l|}{ Welfare generosity } \\
\hline $\begin{array}{l}\text { Fitted benefits \% GDP } \\
\text { (logs) } 1980-90 \text { (host) }\end{array}$ & $\begin{array}{c}-0.018 \\
(0.010)^{*}\end{array}$ & $\begin{array}{c}-0.017 \\
(0.009) * *\end{array}$ \\
\hline $\begin{array}{l}\text { Fitted benefits \% GDP (logs) 1980- } \\
90 \text { (host) X R }\end{array}$ & $\begin{array}{c}0.022 \\
(0.009)^{* *}\end{array}$ & $\begin{array}{c}0.018 \\
(0.011)^{*}\end{array}$ \\
\hline \multicolumn{3}{|c|}{ 4. Dependent variable: Skill Difference Migration Rates, adjusted by Relative Education Quality ${ }^{4}$} \\
\hline \multicolumn{3}{|c|}{\begin{tabular}{|l|l|l} 
Welfare generosity & & \\
\end{tabular}} \\
\hline $\begin{array}{l}\text { Fitted benefits \% GDP } \\
\text { (logs) } 1980-90 \text { (host) }\end{array}$ & $\begin{array}{c}-0.018 \\
(0.010)^{*}\end{array}$ & $\begin{array}{c}-0.019 \\
(0.008) * *\end{array}$ \\
\hline $\begin{array}{l}\text { Fitted benefits \% GDP (logs) 1980- } \\
90 \text { (host) X R }\end{array}$ & $\begin{array}{c}0.022 \\
(0.009)^{* *}\end{array}$ & $\begin{array}{c}0.024 \\
(0.010)^{* *}\end{array}$ \\
\hline
\end{tabular}

Notes: Instrumented using legal origin dummies and the interaction of legal origin dummies and $\mathrm{R} .{ }^{1}$ Both models have all controls as in Table 6, column 3 (6) for DCs (LDCs), but migration rates are interacted by source country Educational Quality. ${ }^{2}$ Both models have all controls as in Table 6, column 3 (6) for DCs (LDCs), but migration rates are weighted by source country Educational Quality. ${ }^{3}$ Both models have all controls as in Table 5, column 3 (6) for DCs (LDCs). ${ }^{4}$ Both models have all controls as in Table 6, column 3 (6) for DCs (LDCs).

Robust standard errors in parentheses; * significant at $10 \%$; ** significant at $5 \%$; *** significant at $1 \%$. 
Appendix:

Table A1: Test Scores

\begin{tabular}{|c|c|c|c|c|c|}
\hline \multicolumn{2}{|c|}{ EUR } & \multicolumn{2}{|c|}{ DC } & \multicolumn{2}{|c|}{ LDC } \\
\hline Country & EQ & Country & EQ & Country & EQ \\
\hline Austria & 5.089 & Australia & 5.094 & Argentina & 3.920 \\
\hline Belgium & 5.041 & Canada & 5.038 & Brazil & 3.638 \\
\hline Switzerland & 5.142 & Hong Kong & 5.195 & Chile & 4.049 \\
\hline Denmark & 4.962 & Israel & 4.686 & China & 4.939 \\
\hline Spain & 4.829 & Japan & 5.310 & Colombia & 4.152 \\
\hline Finland & 5.126 & Korea, Rep. & 5.338 & Egypt & 4.030 \\
\hline France & 5.040 & New Zealand & 4.978 & Indonesia & 3.880 \\
\hline $\begin{array}{l}\text { United } \\
\text { Kingdom }\end{array}$ & 4.950 & Singapore & 5.330 & India & 4.281 \\
\hline Germany & 4.956 & \begin{tabular}{|l} 
Taiwan \\
(Chinese Taipei)
\end{tabular} & 5.452 & Iran & 4.219 \\
\hline Greece & 4.608 & United States & 4.903 & Jordan & 4.264 \\
\hline Ireland & 4.995 & & & Lebanon & 3.950 \\
\hline Italy & 4.758 & & & Morocco & 3.327 \\
\hline Netherlands & 5.115 & & & Mexico & 3.998 \\
\hline Norway & 4.830 & & & Malaysia & 4.838 \\
\hline Portugal & 4.564 & & & Nigeria & 4.154 \\
\hline Sweden & 5.013 & & & Peru & 3.125 \\
\hline & & & & Philippines & 3.647 \\
\hline & & & & Thailand & 4.565 \\
\hline & & & & Tunisia & 3.795 \\
\hline & & & & Turkey & 4.128 \\
\hline & & & & South Africa & 3.089 \\
\hline $\begin{array}{l}\text { Group } \\
\text { Averages }\end{array}$ & 4.939 & & 5.132 & & 3.999 \\
\hline
\end{tabular}

Notes: EQ = average test score in maths and science, primary through end of secondary school, all years (scaled to PISA scale divided by 100).

Table A2: Example of Education Adjustment

\begin{tabular}{|c|c|c|}
\hline Emigration rate of High skilled & Egypt-UK migration & Egypt-Italy migration \\
\hline Unadjusted & 0.2435 & 0.1144 \\
\hline Adjusted: REQ & 0.198 & 0.0969 \\
\hline Adjusted: WEQ & 0.0604 & 0.0284 \\
\hline
\end{tabular}

$R E Q=D M_{.}\left(E Q_{s} / E_{h}\right) ; \mathrm{WEQ}=D M\left(1 / E Q_{s}\right)$ 